\title{
Tradiční hliněná architektura v Íránu a zpưsoby její revitalizace
}

\author{
Martin Novotný
}

DOI: 10.21104/CL.2020.3.04

Traditional earth architecture in Iran and ways of its revitalization

\begin{abstract}
The essay submits basic information about particular types of traditional earth architecture in Iran. The essay emphasizes the ethnological aspect of the researched theme. The continuous uninterrupted building activities in using the earth, which lasted nearby ten thousand years, resulted in houses, domes, prayer rooms, castles, palaces, and several towns, whereby traces left by this very long tradition can be found in the country even today. Notwithstanding the exceptional historical and architectural values of earth structures, it is possible to observe a plethora of historical buildings in modern-day Iran, which have survived as torsos to exemplify the former glory of earth architecture of this country. The activities connected with the revitalization of original earth architecture are bound to the activity of university and research institutions - Yazd, Tehran, Esfahak Mud Centre, which also are taken into consideration in the text.
\end{abstract}

\section{Key words}

Iran, traditional earth architecture, cultural heritage, revitalization of mud structures

\section{Acknowledgment}

Příspěvek vznikl v rámci institucionální podpory pro dlouhodobý koncepční rozvoj výzkumné organizace NÚLK poskytované Ministerstvem kultury ČR v roce 2020 .

\section{Contact}

PhDr. Martin Novotný, Ph.D., Národní ústav lidové kultury, Zámek 672, 69662 Strážnice, Czech Republik; e-mail: martin.novotny@nulk.cz.

Jak citovat / How to cite

Novotný, Martin. (2020). Tradiční hliněná architektura v Íránu a způsoby její revitalizace. Český lid 107, 351-373. doi:http://dx.doi.org/10.21104/ CL.2020.3.04 
Předložená stat' se zabývá v české etnologii, ale i v oborech stavebně technického charakteru, málo frekventovaným tématem, a to tradiční hliněnou architekturu v Íránu. Jedná se o problematiku, k níž v České republice a vůbec v Evropě existuje velmi málo publikovaných výstupů, o které by se zájemce o studium místní stavební tradice mohl opřít. Etnologický aspekt zkoumané problematiky pak téměř zcela absentuje. Jedná se o oblast, která se těší převážně zájmu architektů a stavebních inženýrů. Podrobnější informace $\mathrm{k}$ danému tématu byly publikovány především v perštině, což je často kromě zdařilých vyobrazení, jež doprovázejí text pro zájemce o dané téma, který tento exotický jazyk neovládá, použitelné jen omezeně. Některé statě íránských vědců byly publikovány v anglickém, popř́padě francouzském jazyce a jsou uvedeny v seznamu literatury. Kromě studia literatury byl využit ke zpracování této statě i materiál získaný autorem v rámci terénních výzkumů v letech 2018 a 2019. Tyto byly vykonány v rámci odborné exkurze studentů a pedagogů Technické univerzity ve Vídni, ústavu Stavebních konstrukcí a vývoje, konkrétně Pracovní skupiny pro trvale udržitelné stavitelství.

Studium hliněného stavitelství v Íránu, podobně jako i v dalších blízkovýchodních zemích má důležitý význam i pro studium obdobné problematiky na území Evropy, nebot' může do budoucna přinést cenné informace týkající se např́klad geneze daného jevu. Zde je nutné zmínit terminologii, konstrukční aspekty, pracovní postupy, prolínání stavebních způsobů aj.

Írán je možné bezesporu nazvat „klasickou“ zemí hliněné architektury. Svým charakterem tak spadá do stavební činnosti typické pro oblast Středního a Blízkého východu, kde byl tento stavební materiál v místní architektuře dominantní. Dnes je tomu ovšem jinak a tradiční hliněné stavby ustupují ve velkém měřítku do pozadí. Hlavní prríčiny jsou v podstatě dvě. Tou první jsou častá zemětřesení, která mají pro tento typ staveb fatální následky, nebot' se tato země nachází v tektonicky aktivní oblasti. Druhým důvodem je fakt, že se Írán řadí $\mathrm{k}$ největším výrobcům cementu na světě. Železobeton, nejčastěji ve spojení s pálenými cihlami, pak v současné architektuře převládl a hlína se omezila mimo některé izolované regiony převážně na oblast revitalizace vybrané historické architektury městské i venkovské provenience. Nicméně i při uplatnění těchto moderních stavebních materiálů $\mathrm{v}$ této oblasti lze sledovat pro Středoevropana zajímavé pracovní postupy, jež vycházejí „,z ruky“, to znamená, že jsou tam rezidua připomínající práci s nepálenou hlínou, kde se použití zednického nářadí omezilo na hladítko a stahovací lat'. Omítka na bázi cementu tak byla nahazována dlaní bez použití zednické lžíce a omítníků, 
což je např́iklad ze střední Evropy fotograficky ještě z konce třicátých let 20. století doloženo z oblasti Madarska (Sabján - Buzás 2003: 118-119).

Hlína byla po staletí př́stupná $\mathrm{v}$ geograficky různorodých regionech např́ić Íránem a svému účelu na vesnicích i ve městech sloužila po celá staletí. Její slučitelnost $\mathrm{s}$ vyprahlým podnebím centrální části této země určila, že se stala dominantním stavebním materiálem oblasti, který zde převládl jako tradiční u různých typů budov, jako byly fortifikační stavby, domy, zájezdní hostince - karavanseráje, mešity, lázeňské domy, cisterny na vodu, větrné věže a mlýny.

Lidová architektura v této zemi se v průběhu tisíciletí formovala jednak v závislosti na vyprahlém (aridním) klimatu íránské náhorní plošiny, jednak na nedostatku vhodného stavebního kamene a dřeva. Všudypř́tomným stavebním materiálem se zde stala hlína uplatněná ve stavbách v několika konstrukčních způsobech (Kazemi - Shirvani 2011: 264). V Íránu je hlína výhradně zastoupena na rozlehlém území především ve střední části této země.

$\mathrm{Na}$ severu, $\mathrm{v}$ přilehlém pásu pobřeží Kaspického moře, byly hlavními stavebními materiály hlína (nepálené cihly) a dřevo, které bylo těženo v rychle mizejících dubových lesích Zagrosu. Stěny domů byly v některých př́padech stavěny na kamennou podezdívku. Na jihu země byly hlavními stavebními materiály kámen a dřevo a do jisté míry i sádra. V pobřežních oblastech a na ostrovech v Hormuzském průlivu (např. Kešm) dominoval v místní architektuře kámen. Zdi pak byly stavěny z kamene na sucho nebo pojeného sádrovou či hliněnou maltou. Sádra je obecně široce rozšířeným materiálem v Íránu a používá se jí v mnoha regionech této země (Madanipour 1997a: 1584).

$\mathrm{V}$ rozhlehlé střední části země bylo z hlíny budováno téměř vše, a to od stěn, klenutých střech až po vnitřní vybavení interiéru (čímž byl fakticky z velké části nahrazen nábytek). Použití nedostatkového dřeva se u staveb v pouštních oblastech omezilo pouze na subtilní překlady u vstupů a jako materiál na výrobu jednoduchých dveř́i. Jako armatura hliněného ohradního zdiva se používalo řapíku datlových palmových listů, které jsou velmi houževnaté (Obr. 1).

Úložné a skladovací prostory tak nahradily jednoduchý nábytek např́klad $\mathrm{v}$ podobě truhlic a skř́ní a byly budovány prrímo jako součást stěn a podlah, byly do nich zapuštěny (Naiemi 2018: 223). Ve stěnách se vyskytovaly skladovací niky a police a do podlah se vestavovaly velkoobjemové keramické zásobní nádoby nebo se hloubily dutiny př́mo do kompaktního sprašového podloží. Do sprašových stěn spodních (hloubených) podlaží byly vytesány i žlaby v chlévech. 
Zejména v pouštních oblastech, kde se vyskytovala vysoká sprašová návrší, lze sledovat vývoj vesnic, které byly terasovitě zapuštěny do hliniště. Bytové jednotky obvykle tvořily tř́podlažní domy. Spodní podlaží byla zahloubená zcela do sprašových stěn, to znamená včetně stropů, popř́ipadě byla částečně zahloubená a využívala kompaktního terénu jen jako stěny s tím, že se stropy zaklenuly. Materiál vytěžený př̀i budování zahloubených objektů byl pak použit na výrobu konstrukčních prvků, hliněných malt, omítek, popř́ípadě zásobních objektů volně stojících nebo zapuštěných pod podlahy, které byly předtím jako keramické prvky vypalovány; popř́ípadě i na vnitřní části vertikálních pecí, objemných keramických nádob, jež se dodatečně obezdívaly. Zcela zapuštěné (tedy i s hloubeným stropem) bývaly chlévy pro domácí zvírata, popř́padě primitivní př́střešky sloužící k úkrytu obyvatel v čase ohrožení. Zahloubenou součástí objektů bývaly obilní jámy určené ke skladování obilí. U některých staveb se vyskytovaly hluboké studny, jež sloužily jako inspekční šachty umístěné v ose chanátů (viz dále) a sloužící k údržbě těchto objektů.

Na velké části území Íránu se vyskytují ploché střechy nebo střechy klenuté. Ploché střechy bývaly v místech, kde bylo alespoň malé množství stavebního dř́ví. Kostra střechy byla tvořena silnými, často rozvětvenými větvemi stromů nebo křivými neopracovanými kmeny (Obr. 2). Ty sloužily jako opora pro větve (často velmi subtilní), popř́padě rákosové rohože, které na tuto základní kostru byly kladeny napříč. V jižních oblastech (ostrov Kešm) je možné narazit na rohože hotovené z palmového listí. Svrchní část střechy byla pak tvořena silnou vrstvou hliněné mazaniny (kah-gel) s příměsí řezané slámy. Jedná se o materiál, kterým byly pokrývány (omítány) i stěny. Moderní inovací u plochých střech bylo použití polyetylénové folie pod hliněnou mazaninu (Madanipour 1997a: 1584).

Strmé valbové střechy kryté došky z rýžové slámy nebo spěchu se uplatnily v horské oblasti provincie Gilan, kde se vyskytuje velké množství srážek. ${ }^{1}$ Tento region je charakteristický dále díky hrázděné, v horách roubené, konstrukci zdejších staveb, jejichž základy jsou rovněž dřevěné.

1 Samotná provincie Gilan, rozkládající se mezi severním úpatím pohoří Elbrus a jižním pobřežím Kaspického moře, je po stránce tradičního stavitelství velmi zajímavá a vymyká se stavební činnosti ve zbytku země. Snad proto se zde nachází jediné muzeum v př́rodě v Íránu (anglicky Gilan Rural Heritage Museum). V zásadě se dá rozdělit do čtyř hlavních geografických oblastí, které mají ještě své subregiony, z nichž každá je charakteristická typem venkovského obydlí. Jedná se o Gilanskou nížinu, nízké podhůří pohoří Elbrus, horské pásmo pokryté lesem a ohraničené vysokohorskými loukami a vyprahlé svahy Elbrusu. V jednotlivých částech se vyskytují zajímavé kombinace stavebních materiálů, což se např́klad týká jednak stěn, jednak střech i celkového vzhledu staveb (srov. Taleghani 2010). 
Jako výchozí surovina byl nejčastěji používán dub a sibiřský jilm. Hlína zde byla spíše doplňková stavební hmota, i když podíl tohoto materiálu na stavbě byl značný. Morfologicky se obydlí gilanské planiny vyznačují tím, že budovy jsou vyvýšeny nad zemí, aby byl obytný prostor izolovaný od vlhké půdy. To znamená, že pohledem dnešního stavitelství jsou domy osazeny na jakýchsi pilotech. Rám hrázděných staveb je zde velmi často zbudován $\mathrm{v}$ úrovni nad zemí a osazen na dřevěné roštové základy (hráně seskládané $\mathrm{z}$ kratších žerdí nebo trámků), které byly čtyři nad sebou a byly kladeny ortogonálně (Ghobadian 2009: 45). Tato spodní část konstrukce byla tvořena $\mathrm{z}$ morušového dřeva, které nejlépe odolávalo vlhkosti. Jak v př́padě vyvýšených obytných, tak i hospodářských staveb bylo zajímavé, že podpěrné sloupy nebo zmíněné hráně byly osazeny na vyvýšenou plochu (fakticky základové patky použivané u současných staveb), která byla zhotovena z hliněné mazaniny (čine) a kamenů. Tato spodní část stavby byla pak zapuštěna $60 \mathrm{~cm}$ pod úroveň terénu a základ patky byl tvořen směsí rozdrceného a vrstveného dřevěného uhlí, popela ze dřeva a říčního štěrku. Celková výška těchto hliněných patek se pak pohybovala mezi $120-150 \mathrm{~cm}$. Jednalo se tedy o první konstrukční prvek, kterým se přenášela váha stavby na podloží (Nazidizaji - Regateiro - Tomé 2014: 71). Tím, že nadzemní stavby nebyly pevně spojeny se zemí, byl vytvořen důležitý prvek prodlužující jejich životnost v př́ípadě zemětřesení (Ibid.: 78).

Hlína byla rovněž výplní hrázděné konstrukce a tvořila silnou omítku na stěnách roubených z kulatiny. Hliněné zde byly i podlahy. I po stránce koncepce se zdejší stavby odlišují od té, která se běžně vyskytuje v celém Íránu a obecně na Blízkém východě. Zatímco např́íklad domy středního Íránu jsou skryty za nečleněnými zdmi, zdejší obydlí nabízejí své fasády vnějšímu světu. Toto je vyjádření základního rysu gilanských kulturních hodnot: převaha „otevřeného“ nad „uzavřeným“. V tomto regionu je to ovšem dáno klimatickými poměry, kdy je na jedné straně íránská náhorní plošina, která má převážně pouštní až polopouštní charakter včetně tropických teplot, na straně druhé pak horská, popřípadě podhorská oblast $\mathrm{s}$ dostatkem srážek. Zde nebyla nutnost se ukrývat před spalujícím horkem v uzavřeném prostoru vnitřních zahrad, včetně mnoha stromů. V kontrastu k tomu se v Gilanu jednalo o otevřenou krajinu, kde stál dům poblíž polí, kde byly smazány rozdíly mezi domácím prostorem a přírodním a zemědělským vnějším světem (Nazidijazi - Regateiro - Tomé 2014: 65).

Íránská náhorní plošina, jež je ohraničená pohořími Elbrus, Zagros a Hindu Kuš, je charakteristická nedostatkem vody. Pro potřebu obyvatelstva a pro závlahy hrály od nepaměti důležitou úlohu podzemní vody. 
Ze studní na svazích hor obklopujících pánve byla sváděna voda nejprve $\mathrm{v}$ otevřených kanálech (haranj). Aby se zabránilo jejímu následnému vypařování v nižších polohách, zaváděla se voda do tunelů (chanátů), které procházely vesnicemi a zásobovaly vodou obyvatelstvo a přilehlá pole. Na zavlažování podzemní vodou byla závislá asi třetina vesnic. Chanáty tedy přinášely život do pouště a mimo jiné na ně byly vázány rezervoáry vody a zásobníky ledu.

\section{Hliněná architektura v Íránu a stavební princip tzv. východní medite- ránní tradice}

První stopy osídlení íránské náhorní plošiny se datují do 8. tisíciletí př. n. l. Doslova uplácané hliněné objekty natěsnané těsně k sobě zde tak vytvořily první lidská obydlí (Hanachi et al 2010: 129). Výsledkem nepřetržité stavitelské kontinuity ve využívání hlíny, trvající takřka deset tisíc let, byly domy, chrámy, modlitebny, hrady, paláce a několik měst, které je možné v této zemi stále dohledat. To jsou symboly íránské historie, podobně jako i v sousedních regionech.

V oblasti Blízkého východu se od starověku až do recentní doby vyskytovala základní koncepce zdejší architektury. Typickou zde byla atriová dispozice $\mathrm{s}$ větším počtem samostatně přístupných menších prostor, která zde byla obvyklá napříč architekturou náležející odlišným uživatelům a sloužící $\mathrm{k}$ odlišným funkcím $\mathrm{v}$ městském i venkovském prostř̌edí. Privilegované i neprivilegované prostředí, obytná i veřejná architektura takto rozvíjela na Blízkém východě stejné architektonické zásady, jež ve východomediteránní oblasti existovaly po celý starověk v obytné i palácové architektuře počínaje Mezopotámií. Tato koncepce životaschopná v architektuře Íránu až do sedmdesátých let 20. století zhodnocovala bydlení eliminací průchozích místností, uspokojením větších nároků na soukromí, umožňovala lepší větrání, jednodušší osvětlení než prostory za sebou a byla vhodným řešením pro bydlení rozšířené rodiny. $\mathrm{V}$ kombinaci s pavlačí, vnitřním dvorem a větší prostorou (aiwan - iván), které plnily funkci společného, respektive společenského prostoru, nabízela vyšší standard bydlení. Privilegované i neprivilegované prostředí, obytná i veřejná architektura takto rozvíjela ve východním mediteránním prostředí stejné architektonické principy. Paralely tohoto „starověkého projekčního řešení "lze pak hledat i v lidové architektuře v oblasti Balkánu (Langer - Bočková 2010: 644-645).

Hliněná architektura se obecně vyznačuje použitím hliněného stavebního materiálu. $\mathrm{V}$ aridních oblastech Íránu se v převážné většině př́ípadů jednalo o materiál eolického původu, o spraš. Tento materiál, který je 
ve své podstatě v oblasti hliněného stavitelství všestranný, našel v místní architektuře široké uplatnění. Od použití jako doplňkového staviva (i když s vyšším procentuálním zastoupením), jak bylo naznačeno výše, se jednalo o stavební hmotu, ze které byly hotoveny hloubené objekty, používal se na výrobu podlah, stěn, omítek, malt i jako nosná konstrukce střech.

Jako nejjednodušší a zároveň i nejstarší hliněné stěny se dají chápat stěny v uměle vytvořených zemních objektech. V Íránu podobně jako v jiných oblastech Blízkého východu mělo budování hloubených prostor nejrůznějš́ho charakteru tisíciletou tradici. Sloužily $\mathrm{k}$ bezpečnému uskladnění potravin a úrody, dále jako transportní komunikace tekoucí vody (již výše zmíněné chanáty) a také jako úkryty v době ohrožení, popř́padě jako obytné prostory určené k přečkání během tropického počasí. Většinou se jednalo o stěny objektů zahloubených ve vhodném podloží. Při zhotovení stěn, popř́padě stropu, se převážně původně využívalo jeho kompaktnosti, což dokonale zajištovalo sprašové podloží.

Od starověku až do současnosti se v oblasti Íránu vyskytovaly geniální inženýrská díla chanáty (podzemní kolektory vody), které přiváděly podzemní vodu z hor dolů do obdělávaných oblastín ${ }^{2}$ (Behnia 1987). Na tyto chanáty byly velmi často ve větších domech i v zájezdních hostincích (karavanserájích, khanech či robatech) napojeny svým umístěním „klimatizované“ podzemní prostory, které byly určeny $\mathrm{k}$ úkrytu před tropickým sluncem. Jistým způsobem se jednalo o samostatná patra, jež byla umístěna i $20 \mathrm{~m}$ pod úrovní podlahy př́izemí. Zajímavým př́́kladem může být $\mathrm{v}$ tomto ohledu někdejší velký karavanseráj, dnes Vali Traditional Hotel v městě Jazd, které je považováno za nejstarší a největší hliněné město na světě. Tisíciletou tradici v Íránu až do recentní doby měla i zemní sila (obilní jámy) sloužící k dlouhodobému uskladnění či úschově zrna. Charakteristickým znakem těchto zásobnic, vykopaných vertikálně až do hloubky čtyř i více metrů pod úroveň okolního terénu, byl parabolický profil jejich klenutí (zakřivení stěn), aby nedocházelo k destrukcím. Zahloubené byly i podpovrchové části sofistikovaných skladišt' ledu zvaných Yakhal (Obr. 3), kde při dodržení vhodných podmínek vydržel led i během horkých letních dní, aniž by roztál (Javadi 2018: 11). Zahloubené byly i spodní části vodních rezervoárů ( $a b$ anbar).

2 Podle oficiálních statistik bylo k roku 2010 v zemi evidováno 37000 chanátů (Javadi 2018: 74). 


\section{Hliněný stavební materiál v Íránu v návaznosti na blízkovýchodní stavební tradici}

Hlínu určenou pro stavební účely nadzemních objektů bylo ovšem nutné upravit do použitelné podoby bud' v amorfním stavu, nebo do podoby stavebních prvků. V Íránu, podobně jako v jiných oblastech Blízkého východu je možné se setkat $\mathrm{s}$ oběma variantami. V souvislosti s hliněným stavitelstvím je obecně v povědomí nejrozšířenějším stavebním prvkem nepálená cihla. Ta má v regionu tisíciletou tradici. ${ }^{3}$ I použití tohoto stavebního způsobu se ve sledované oblasti, podobně jako i jinde vyskytovalo v řadě variant (Obr. 4).

V místech, kde se měla dobývat hlína, bylo nutné odstranit svrchní část, tedy travní drn, kamení a kořeny rostlin. Obvykle se jednalo o vrstvu $30-50 \mathrm{~cm}$. Př́i dobývání stavební hmoty se používal krumpáč (špičák), motyka, rýč, lopata, kolečko, koš, kbelík. Jako příměsi bylo používáno řezané slámy, jež se připravovala na řezačce píce. V oblastech, kde se vyskytovala hlína s obsahem soli, která pokud byla použita ihned na stavbu, způsobovala absorpcí vlhkosti i ze vzduchu degradaci stavebního materiálu. ${ }^{4}$ Aby se zabránilo těmto negativním účinkům soli obsažené ve stavební hlíně, což bylo doloženo i v řadě oblastí Íránu, bylo nutné takto vytěženou stavební surovinu jeden nebo dva roky před plánovanou stavbou nechat odležet (zvětrat) a sůl nechat dešti postupně odplavit (Baimatowa 2008: 25).

První fází při výrobě výchozí suroviny (hliněného těsta) bylo vlhčení a její následné několikadenní odstavení, aby se zpracovaná hmota důkladně homogenizovala. Při fázi vlhčení se zpravidla postupovalo v poměru 3:1, to znamená, že se ke třem vědrům suché hlíny přidávalo jedno vědro vody. Ve střední Asii a potažmo i v Íránu (jakož i v jiných oblastech) probíhalo mísení bud' pomocí vyšlapávání bosýma nohama, nebo pomocí zvířat, zde konkrétně koní nebo oslů (Baimatowa 2008: 28). Do hlíny se podle potřeby přidávaly příměsi, které zlepšily její mechanické vlastnosti. Nejčastěji se jednalo o řezanou slámu (používána byla napr. sláma rýžová).

Mistr, který stavěl hliněné stavby, byl ve střední Asii a v Íránu nazýván devăr-kaš, čineh-kaš. Íránsky hovořícím obyvatelstvem byly hliněné cihly nazývány $\underline{\text { hišt} . \text { V Íránu je jedna cihla nazývána jako } \underline{h} e s ̌ t . ~ V e ~ s t a r o v e ̌ k u ~ b y l y ~}$ hliněné cihly označovány ištty' $a,(h) i \check{s} t i s ̌$. Výrobou hliněných cihel se zde zabývali speciální řemeslníci nazývaní heštgar, heštzan, heštmāl. V Íránu byly

3 Nejstarší doklady použití hliněných cihel z oblasti Blízkého východu pocházejí z 9. tisíciletí př. n. l. (Schröder 2010: 2).

4 Zajímavé př́íklady z oblasti Uzbekistánu uvádí E. Blomkvistová (1956: 95). 
termínem čineh označovány celé hliněné stěny (Baimatowa 2008: 25). ${ }^{5}$ V oblasti se vyskytovaly i stavby budované technologií tzv. nabíjeného zdiva.

Pokud se týká použití hlíny jako konstrukčního prvku v její amorfní podobě, je možné se setkat v Íránu s oběma dostupnými variantami. Jako nejstarší způsob stavby hliněného zdiva se uvažuje o tzv. vrstvení, v místním jazyku obecně označované jako čineh, jak již bylo naznačeno výše. Charakteristickým rysem pro tuto stavební techniku je volné kladení homogenizované hliněné směsi do zdiva. ${ }^{6}$ Tato technika jistým způsobem připomíná lepení vlaštovčího hnízda. Jako př́íměsi bylo používáno nasekané slámy, popřípadě jiných rostlinných vláken. Stěna se zde vrstvila ručně a směrem ke koruně se ze statických důvodů zužovala (Obr. 6) (Madanipour 1997b: 1587). S pozůstatky po této stavební technologii je možné se dodnes setkat v Íránu u staveb nejrůznějšího charakteru, a to zejména v nejstarší dochované stavební vrstvě staveb (Zargar 2007: 224). Zajímavým dokladem je naprŕ́klad hliněná zřícenina citadely Narin Qal>eh, která leží u města Nain ve středním Íránu a jejíž počátky sahají do 5. tisíciletí př. n. 1., kde byla tato technologie použita ve fortifikaci, popř́ípadě zemětřesením zničená vesnice Esfahak, kde se vrstvení (čineh) vyskytovalo ve zdivu u obytných staveb. Technologie vrstveného zdiva se později uplatnila u podružných typů konstrukcí a její použití se omezilo pouze na ohradní zdivo, jednak jako vysoké stěny okolo obytných domů a proslulých perských zahrad, jednak ve formě předstěn u chladičů ledu (Yakhal) chránících tyto stavby před účinky slunce z jižní strany.

Další v terénu zachycenou stavební technikou, nicméně oproti předchozí již sofistikovanější, pracující s amorfní hlínou byla nabíjená technika. Jejím principem bylo pěchování hliněné směsi v dřevěném bednění, tedy mezi dvojici fošen, které vytvářely jakousi rozebíratelnou formu. V souvislosti s nabíjenými stěnami bylo u recentních staveb v Íránu zjištěno nabíjené zdivo do bednění tzv. jařmového typu. Tento nástroj, který měl tvar rámu, se skládal z př́́držných trámků, jež se kladly vodorovně kolmo

5 Terénním výzkumem (2019) autora v lokalitě Esfahak ve východním Íránu bylo zjištěno, že se termín čineh (čine) používal jednak i pro stavební techniku již zmíněného vrstveného zdiva (Obr. 5), jednak pro stavbu z hliněných válků v jejich amorfní podobě (velké hroudy hlíny s obsahem slámy). Ručně formované stavební prvky hliněné masy se v oblasti stř̌ední Asie označovaly termínem kulāla (guvala, guvalak) - [odtud snad slovanský termín válek - pozn. autora] rozměrů 25-20 × 10-9 cm, které se používaly jako speciální stavební materiál ke zdění stěn a jako výplň hrázděné konstrukce (dřevěného rámu). Po uložení se tyto prvky zdeformovaly na ovál (Baimatowa 2008: 25).

6 Např. v Jemenu se pro obdobný stavební způsob používalo termínu zabur (Minke 2009: 84-85). 
napříc stěnou a z každé strany ji přesahovaly. Do otvorů v přečnívajících koncích byly vsazeny spodní ćásti svislých ramen, která byla oporou pro fošny. Oba horní konce ramen byly spojeny lištou, obdobou spodního př́držného dřeva. Když se bednění zvedalo, celá konstrukce se rozebrala a rám se znovu postavil na vrchol stěny. Vodorovný př́ídržný spodní trámek, který po zaplnění prostoru hlínou a odbednění zůstal ve stěně, se následně vyrazil. Ve zdivu zůstaly poté zachovány charakteristické otvory, jež slouží k identifikaci použité technologie (Novotný 2014: 42). Tato stavební technika byla ve velkém měřítku doložena i v mladších vrstvách opevnění již citované zříceniny Narin Qalıeh.

Rozšířenějšími stavebními způsoby byly stěny budované $\mathrm{z}$ předem připravených stavebních dílců. Nejstaršími kusovými stavebními prvky byly hliněné války. Obecně se tímto termínem označuje stavební dílec, jenž je připraven odhadem bez formy, která by mu udávala přesnější tvar. Za základní charakteristický znak této stavební techniky bez ohledu na způsob uložení jednotlivých válků do stěny je skutečnost, že se $\mathrm{v}$ naprosté většině př́padů stavělo z ještě vlhkých dílů. Ty se bez pojiva (hliněné malty) vzájemně lepily k sobě. U recentních objektů v Íránu je možné dohledat rezidua této stavební technologie, a to v její nejarchaičtějš́i podobě jako beztvarých hrud hlíny, které se vzájemně lepily $\mathrm{k}$ sobě a opět v použití u podřadnějších konstrukcí (např. ohradní zdivo v lokalitě Abarkuh jihozápadně od Jazdu v centrální části země). Vyspělou formu válkových stavebních dílců, které bylo možné považovat za přechodovou formu k cihelnému zdivu, představovaly v rukách uhnětené stavební prvky blížící se tvarem cihle, dopředu vyschlé a kladené na hliněnou maltu. Rozdíl oproti nepálené cihle byl v tom, že se jednalo o stavivo, jehož tvar byl přesně určován formou, ve které se formoval. ${ }^{7}$ Zajímavé archeologické doklady hliněných válků, cihel, armovaných stavebních prvků i hliněných překladů ze sledované oblasti publikoval Horst Schröder (Schröder 2010: 7).

Paralelně s použitím hlíny v její amorfní podobě, popř́padě v podobě nepravidelných stavebních prvků mělo v regionu tisíciletou tradici zdění z nepálených cihel. V Íránu je doložena řada variant, které se týkají velikosti stavebních prvků a způsobů kladení do zdiva. Ve starších vrstvách fortifikací (např. citovaná zř́cenina Narin Qal`eh), kde byly rozměry cihel $40 \times 20 \times 10 \mathrm{~cm}(\mathrm{~d} \times$ š $\times \mathrm{v})$, ale i obytných domů (Esfahak), je možné na-

7 Např. v oblasti střední Evropy (zejména na Moravě v ČR) se ještě u recentních staveb dochovalo velké množství konstrukčních způsobů pracujících s hliněnými války. V terénu byly doloženy i varianty používající proschlé stavební dílce nepravidelného tvaru pojené hliněnou maltou (podrobněji viz Novotný 2014). 
razit na velkoformátové cihly, které byly hotoveny do forem. Jednalo se o kvádry, které měly rozměry $47 \times 27 \times 14 \mathrm{~cm}(\mathrm{~d} \times$ š $\times \mathrm{v})$. Ve zdění byla dodržena nejčastěji vazáková vazba kladení stavebních prvků. N. Baimatowa uvádí rozměry cihel používaných íránskými Parthy, které byly $56-38 \times$ $36-16 \times ?$ ? $(\mathrm{d} \times \check{\text { š }} \times \mathrm{v})$ nebo $44 \times 27-13 \times 5 \mathrm{~cm}$. Ve východním Turkmenistánu se vyskytovaly cihly, jejichž délka dosahovala až $61 \mathrm{~cm}$. Velkoformátové cihly zde byly použity k vybudování konzolové kupole. Hrobové komory poblíž Biškeku byly klenuty s přibližně $46 \mathrm{~cm}$ dlouhými a přibližně $18 \mathrm{~cm}$ širokými pravoúhelnými hliněnými cihlami. Jedna z jejích dvou kratších stran byla pod úhlem přiseknuta tak, aby se dvě cihly mohly opř́t o sebe (Baimatowa 2008: 37).

Vůbec nejrozšířenějším stavivem se v Íránu staly hliněné cihly unifikovaných rozměrů ca $20 \times 20 \times 5 \mathrm{~cm}(\mathrm{~d} \times \check{\mathrm{s}} \times \mathrm{v})$. Jednalo se o univerzální materiál, který sloužil ke stavbě stěn a rovněž i kleneb, tedy fakticky střech u objektů v pouštní oblasti. Důvodem, proč tento materiál vytlačil velkoformátové stavební prvky, byla bezesporu variabilita jeho použití, $\mathrm{s}$ čím je možné se ještě dnes setkat $\mathrm{u}$ řady staveb $\mathrm{v}$ terénu, popř́ípadě i během revitalizací. Variabilita se uplatnila jednak při zdění samotného zdiva, jednak v př́ípadě klenutí, které se zde provádělo zásadně bez dřevěného bednění, nebot dřevo bylo nedostatkovým materiálem (Minke 2009: 182). Použití cihel majících v půdorysu čtvercový tvar má v oblasti Íránu tisíciletou tradici. Archeologické doklady z lokality Sialk dokládají čtvercové cihly o rozměrech stran $20-25 \mathrm{~cm}$ a výšce $5-6 \mathrm{~cm}$ nebo $38-50 \mathrm{~cm}$ a výšce 9-12 cm ve 4. tisíciletí př. n. l. (Hejazi - Hejazi - Hejazi 2015: 206).

Zdivo bylo nejčastěji budováno běhounovou/vazákovou vazbou. Rozdíl zde nemohl být patrný, nebot' se jednalo o prvky čtvercového tvaru. V návaznosti na úsporu stavebního materiálu se používalo i komůrkového zdiva, u kterého se pracovalo se stavebními prvky kladenými na výšku (Obr. 7). V souvislosti s touto konstrukcí je možné narazit na termín vazba krysí pasti (Ghobadian 2009: 99). V líci zdiva to pak vypadalo tak, že se vždy střídala jedna cihla podélně (běhoun) s cihlou kladenou napříč (vazák) do hloubky. Vzniklý prostor (komůrka) byl pak vyplněn hliněnou mazaninou.

V Íránu, v centrální části země, je možné narazit i na klasovitou vazbu zdiva budovanou z nepálených cihel výše naznačeného formátu $(20 \times 20$ $\times 5 \mathrm{~cm}$ ). Zdění stěn klasovitou vazbou bylo jedním z typických stavebních způsobů použití tohoto staviva zejména na severu Íránu v provincii Gilan. Zde byly dokumentovány i stavební postupy z prvků tvarovaných bez formy jen odhadem v rukách a dosahujících délky až $35 \mathrm{~cm}$. Vzhledem $\mathrm{v}$ líci zdiva tato vazba připomínala klasovité zdivo doložené a podrobně dokumentované v ČR na střední Moravě (Novotný 2014: 54-64). 
Princip klasovité vazby do hloubky zdiva v provincii Gilan podrobně zdokumentoval Mahmoud Taleghani (Obr. 8). Hloubka stěny byla dána šířkou dvou použitých stavebních prvků kladených do zdi vedle sebe, to znamená, že při použití cihel formátu $20 \times 20 \mathrm{~cm}$ se jednalo o $40 \mathrm{~cm}(\mathrm{Ta}-$ leghani 2010: 70-72).

\section{Revitalizace tradiční hliněné architektury}

Írán patří k zemím, které je možné nazvat „klasickými oblastmi hliněné architektury“. V zemi je dodnes zachováno velké množství tradičních hliněných staveb, ale většina $\mathrm{z}$ nich podléhá velmi rychle modernizaci, respektive starší zástavba skokově ustupuje zástavbě nové. Těchto jevů si je vědoma i místní vláda, která se snaží rozvíjet programy (i mezinárodní) na záchranu a revitalizaci i tradičních hliněných staveb. Ta probíhá na vládní i akademické úrovni. Velký podíl na záchraně tohoto druhu architektury má rovněž turistický ruch zejména $v$ oblasti tzv. agroturistiky, která je v Íránu v současnosti na vzestupu. Některé z významných památek, reprezentantů zdejší hliněné architektury, byly v posledních letech zapsány do prestižního seznamu UNESCO. Mezi nejznámější patřri citadela Bam, historické jádro města Jazd a vesnice Abyaneh. Systematické snahy o institucionální záchranu tradiční hliněné architektury se v Íránu začaly postupně objevovat od osmdesátých let 20. století.

V roce 2006 bylo na Teheránské univerzitě založeno multidisciplinární výzkumné a vzdělávací středisko Institut aplikovaného výzkumu íránské kultury (IICAR). Tato instituce provádí aplikovaný výzkum i v řadě společenských oborů včetně kulturního a architektonického dědictví. Jedním z klíčových úkolů této instituce bylo vypracování koncepce a zbudování prvního muzea v prŕrodě v Íránu. Projekt zaměřený na region Gilan (Guilan Rural Heritage Museum), pobřežní oblasti Kaspického moře na severozápadě země, byl realizován v důsledku následků katastrofálního zemětřesení, které tuto oblast postihlo v roce 1990 a mělo zhoubný dopad na tradiční venkovskou zástavbu. ${ }^{8}$ Zevrubné etnografické a architektonické výzkumy v této oblasti identifikovaly devět kulturně-architektonických subregionů. Každá z těchto podoblastí je v muzeu reprezentována samostatným areálem (vesnicí), kam byly transferovány vytipované původní objekty. Institut IICAR vydává ve spolupráci s muzeem v př́rodě v Gilanu vědecké publikace o venkovské architektuře regionu. V souvislosti

8 Novostavby v této oblasti, podobně jako v jiných částech Íránu se nově zcela vymykají lokální stavební tradici. V Gilanu mají v současné době obytné domy nosné konstrukce stěn i stř̌echy z ocelových profilů. 
$\mathrm{s}$ tématem tohoto př́spěvku zaměřeného na tradiční hliněné stavitelství v Íránu a možnosti jeho revitalizace je neméně zajímavý druhý, již citovaný, svazek této ediční řady La maison Amini, ve kterém je detailně popsána a zdokumentována řízená demolice pozoruhodné klasovité vazby hliněného zdiva jako podkladu pro jeho opětovnou stavbu (viz Taleghani 2010). Dalším úkolem výzkumného centra IICAR je př́prava koncepce a zbudování druhého íránského muzea $\mathrm{v}$ př́rodě, které má prezentovat stavební tradici provincie Golestán na jihovýchodním pobřeží Kaspického moře. Př́prava tohoto projektu probíhá $\mathrm{v}$ současné době na základě spolupráce s Výzkumným ústavem íránské organizace kulturního dědictví, řemesel a cestovního ruchu. Na tomto projektu spolupracuje s IICAR čtrnáct dalších odborníků a výzkumných pracovníků z oblasti architektury, ochrany a obnovy stavebních památek a etnologie. ${ }^{9}$

V roce 2006 zahájila činnost další významná instituce, která pečuje o stavitelské kulturní dědictví Íránu. Jedná se o Výzkumné centrum rurální architektury, jež bylo zř́zeno v rámci Fakulty architektury na univerzitě ve městě Jazd, ${ }^{10}$ které je považováno za nejstarší hliněné město na světě. Mezi hlavní oblasti činnosti tohoto centra náleží aplikovaný výzkum tradičních hliněných staveb. Od roku 2017 k němu přibylo nově zrízené Mezinárodní centrum pro výzkum větrných mlýnů. Součástí vybavení výzkumného centra rurální architektury jsou i laboratoře, které slouží $\mathrm{k}$ analyzování historického hliněného materiálu i $\mathrm{k}$ ověřování fyzikálně-mechanických vlastností výrobků určených $\mathrm{k}$ adaptacím stávajících staveb. Toto výzkumné středisko pravidelně organizuje mezinárodní workshopy a semináře zaměřené na obnovu tradičních hliněných historických konstrukcí a způsobů jejich revitalizace (Obr. 9); organizuje rovněž mezinárodní symposia o hliněném stavitelství (Symphosium of Adobe Sculpture). Není náhodou, že Výzkumné centrum rurální architektury bylo založeno právě v Jazdu. Jedná se o město, jehož historické centrum tvořené unikátní tradiční hliněnou architekturou bylo zapsáno na seznam kulturního dědictví UNESCO. Původní obyvatelstvo pomalu opouští své př́bytky $\mathrm{v}$ historickém jádru města a stěhuje se do moderních staveb na okraji. Někdejší obytné domy, zájezdní hostince a domy bohatých kupců jsou postupně adaptovány na hotely a zázemí pro turisty. To je jistým způsobem záchrana těchto unikátních objektů, které se stávaly postupně vybydlenými.

9 Odkaz, kde je možné získat základní přehled o činnosti organizace IICAR: http://iicar.ut.ac.ir/ShowContent.aspx?PageID=450.

10 Odkaz, kde je možné získat základní přehled o Fakultě architektury na univerzitě v Jazdu: https://yazd.ac.ir/en/schools/art/dept/architecture. 
Př́činou ústupu tradiční (zejména venkovské) architektury jsou i poměrně častá zemětřesení, kterým velmi často podléhají právě hliněné stavby. Přeživší obyvatelé již své původní domy neobnovují, ale často postaví úplně nové vesnice mimo intravilán původního sídla. Př́kladem může být v textu již několikrát citovaná historická vesnice Esfahak, která se nachází asi $35 \mathrm{~km}$ východně od města Tabas, v provincii jižní Chorasán, a která byla kontinuálně osídlena více než 1400 let (Obr. 10). Původní vesnice byla opuštěna $\mathrm{v}$ důsledku devastujícího zemětřesení, které ji zasáhlo v roce 1978 a při kterém zahynulo velké množství místních obyvatel. Po opuštění zničených domů se zrychlil proces eroze (zejména stěn a klenutých hliněných střech) a původní vesnice byla odsouzena k zániku. V důsledku zvýšeného zájmu o kulturní dědictví i v návaznosti na nově nastupující trend agroturistiky využívající adaptovaných lidových staveb dochází po třiceti pěti letech k postupné obnově někdejší hliněné vesnice, jíž se tak díky turistice dostalo nového života. Iniciativy se ujali potomci přeživších, kteři si byli vědomi výjimečnosti místa. Projekt začal statickým ohledáním staveb a vytipováním objektů, které byly určeny k postupné revitalizaci. Iniciativy se ujal přední odborník na restaurování historických hliněných staveb architekt Faramarz Parsí, jenž je autorem projektu Esfahak - revitalizace a obnova historické vesnice, přičemž architekti společnosti EK navrhli opatření na konstrukční zpevnění adaptovaných staveb včetně instalačních detailů. ${ }^{11}$ Proces obnovy této historické vesnice začal naplno v roce 2014. Potenciál Esfahaku kromě ideálního místa pro ekoturistiku navíc spočívá v tom, že se stal místem, kde bylo zř́zeno Centrum hliněného stavitelství (Esfahak Mud Center), a nástavbou je tak i jeho edukační přesah. Pravidelně se zde konají kurzy restaurování zaměřené na tradiční hliněnou architekturu. Jejich účastníky jsou jak studenti technických a restaurátorských oborů domácích univerzit (Teherán, Isfahán), tak i studenti z vysokých škol z Rakouska, Francie a Itálie.

11 Faramarz Parsí je členem společnosti Emarat Khorshid (EK) Consulting, založené v roce 2000 , která se specializuje na architekturu, restaurování a urbanismus se zaměřením na historickou íránskou architekturu. Cílem je obnova a revitalizace vybraných staveb a jejich citlivá adaptace sloužící současným potřebám. EK úzce spolupracuje s Íránskou vládní organizací pro kulturní dědictví (ICHTO) a podílí se na př́pravě podkladů pro dokumenty na seznam světového kulturního dědictví UNESCO. Tato společnost rozvíjí také projekty na mezinárodní úrovni. Př́íkladem může být spolupráce s italským institutem Assorestarato (The Italian Association for Architectural, Artistic and Urban Restoration) na pořádání mezinárodních konferencí o seizmické výztuze a strukturální rehabilitaci historických staveb (Tabríz, 2016) a obnova a ochrana fasád historických budov (Isfahán, 2016). Základní informace o revitalizaci historické vesnice Esfahak a o činnosti společnosti Emarat Khorshid viz http://www.caoi.ir/en/projects/item/1038-esfahak-historic-village.html. 
V současné době probíhá v obci obnova více než dvaceti vytipovaných staveb, na které se podílejí místní stavební firmy. Revitalizována tak byla místní historická mešita, původní lázeň (hamam) a některé domy. Důraz je kladen na dodržování tradičních stavebních postupů. V místě jsou ručně vyráběny nepálené hliněné cihly potřebných formátů, ze kterých je vyzdíváno zničené historické zdivo, popř́padě obnovovány klenby. V lokalitě jsou rovněž obnovovány historické hliněné, popř́ípadě i původní sádrové omítky. Citlivá adaptace se dotýká i původní hliněné nezpevněné komunikace, která procházela obcí a pro pohodlnější pohyb je nahrazována dlažbou. Interiéry objektů jsou obnovovány $\mathrm{v}$ duchu tradice se spaním na matracích na podlaze. Pro zájemce o architekturu je Esfahak doslova encyklopedií rudimentálních staveb. Díky množství destruovaných objektů je možné zachytit pozoruhodné stavební detaily, jako jsou podzemí zahloubené části staveb, klenby, trasologie nástrojů používaných k hloubení, topeniště, inspekční studny do chanátů, obilní sila, řešení překladů, zavlažovací kanály, podrobná struktura stěn a další, které u stávajících objektů bývají často skryty pod omítkou.

V Jazdu a podobně i v dalších lokalitách, kde probíhá obnova stávajících hliněných staveb, je možné sledovat práci stavebních dělníků, zedníků i štukatérů, jak postupují při realizacích oprav. Míchání hliněné směsi potřebné na výrobu nepálených cihel, popřípadě malt a hliněných omítek, do níž se nejčastěji přidává řezaná sláma, se většinou provádí nohama, na které jsou obuty holínky. Materiál se obvykle míchá do podoby velmi ř́́dké konzistence, tak aby šel rovnoměrně a jednoduše homogenizovat, poté se nechá nějakou dobu odležet, aby se jednotlivé komponenty správně propojily a aby odležením ztratil přebytečnou vlhkost. V některých lokalitách je možné narazit na ruční výrobu hliněných cihel, ale velmi často se pracuje s materiálem z cihelen, se sušenými cihlami, které neprošly výpalem (popř́padě prošly jen částečným). Jako námezdní dělníci bývají velmi často najímáni Afghánci, kteři před válkou v jejich zemi uprchli do Íránu. Pozůstatky tradičních stavebních postupů, upomínající na někdejší práci s hlínou (tedy práci „z ruky“), je možné v některých případech nalézt i při stavbách z moderních materiálů, např́klad při omítání cementovou maltou. Ilustrativní prípad byl v roce 2018 autorem zaznamenán na ostrově Kešm, kde nebyla při omítání využita zednická lžíce, ale ruka (v rukavici). Na stěně nebyly vytvořeny omítací platky a omítka byla volně „od oka“ stahována pouze stahovací latí a poté uhlazena hladítkem.

$\mathrm{S}$ ústupem tradiční hliněné architektury se obecně mezi obyvatelstvem velmi rychle v současné době vytrácí původní technologické znalosti při práci s hlínou, které místní nutně potřebovali v souvislosti s periodickou údržbou svých hliněných staveb ovládat. Např́klad v lokalitě Esfahak 
se dnes jedná mimo pracovníky firem podílejících se na obnově vesnice již jen o starší původní občany, kteř́ si v ruinách někdejších hliněných staveb částečně zachovali svá hospodářství. Konkrétně jde např́íklad o míchání hliněné směsi se slámou na opravu hliněné zdi sloužící jako oplocení.

Otázku dalšího života hliněné architektury v Íránu tak přebírají citlivě prováděné adaptace původních hliněných staveb, které jsou v souladu s technologickými a konstrukčními zásadami jejich obnovy zárukou jejich zachování pro budoucí generace. Na př́klady zdařilých adaptací je možné narazit i v dalších městech a vesnicích, jako je Kašán, Širáz, Esfahán, Abarkuh, Teherán, Abyaneh, Khanaraq a dalších (Obr. 11, 12).

Srpen 2020

\section{Literatura}

Baimatowa, Nasiba S. 2008. 5000 Jahre Architektur in Mittelasien. Lehmziegelgewölbe vom 4./3. Ft. v. Chr. bis. Zum Ende des 8. Jhs. n. Ch. Mainz: Von Zabern.

Behnia, A. 1987. The Qanat: Construction and Maintenance. Tehran: TEH: University.

Blomkvist, Je. E. 1956. Krestjanskie postrojki Russkich, Ukraincev, Belorusov. In: Tokarev, S. A. (red.): Vostočnoslarjanskij etnografičeskij sbornik. Očerki narodnoj materialnoj kultury Russkich, Ukraincev i Belorusov v IXX - načale XX v. Moskva: Izdatel'stvo Akademii nauk SSSR: 3-458.

Ghobadian, Vahid. 2009. Sustainable traditional buildings for Iran. A climatic analysis. Lebonon, Beirut: Islamic Azad University.

Hanachi, Pirooz et al. 2010. Towards Sustainable Earthen Architecture, with Special Reference to Iran. In: Lehmann, Steffen - Al Waer, Husam - Al-Qawasmi, Jamal (eds.): Sustainable architecture and urban development. SAUD, The Seventh International Conference of The Center for the Study of Architecture in the Arab Region 1. Amman, Jordan: CSAAR Press: 129-145.

Hejazi, Mehrdad - Hejazi, Bina - Hejazi, Saba. 2015. Evolution of persian traditional architecture through the history. Fournal of architecture and urbanism 39: 188-207.

Javadi, Seyed Mohammad Reza. 2018. Millennial Mastery over Earth, Water and Wind in Iran. Yasoun.

Langer, Jiří - Bočková, Helena. 2010. Obydlí v Karpatech a prìlehlých oblastech balkánských. Ostrava: Šmíra-Print. 
Kazemi, Amir Ghayour - Shirvani, Amir Hosein. 2011. An Overview of Some Vernacular Techniques in Iranian Sustainable Architecture in Reference to Cisterns and Ice Houses. Fournal of Sustainable Development 4: 264-270.

Madanipour, Ali. 1997a. Bakhtiari. In: Oliver, Paul (ed.): Encyclopedia of Vernacular Architecture of the World. Vol. 2. Cambridge - New York Melbourne: Oxford Brookes University:1583-1584.

Madanipour, Ali. 1997b. Khuzestán: Arabs. In: Oliver, Paul (ed.): Encyclopedia of Vernacular Architecture of the World. Vol. 2. Cambridge - New York - Melbourne: Oxford Brookes University:1587.

Minke, Gernot. 2009. Handbuch Lemhbau: Baustoffunde, Technike, Lehmarchitektur. Sedmé vydání. Staufen bei Freiburg: Ökobuch.

Naiemi, Atri Hatef. 2018. Residental Compounds: Earthen Architecture in the Central Desert of Iran. In: Pradines, Stéphane (ed.): Earthen Architecture in Muslim Cultures. Historical and Anthropological Perspektives. Leiden - Boston: Brill: 203-232.

Nazidizaji, Sajjad - Regateiro, Francizco - Tomé, Ana. 2014. The architecture and construction proces of the vernacular Shikili Houses in Gilan, northern Iran. Construction History: 63-82.

Novotný, Martin. 2014. Hlinèné stavitelství na Moravě a evropské souvislosti. Kritický katalog k výstavě. Strážnice: Národní ústav lidové kultury.

Sabján, Tibor - Buzás, Miklos. 2003. Hagyományos falak. Budapest: Terc Kft.

Schröder, Horst. 2010. Lehmbau. Mit Lehm ökologisch planen und bauen. Wiesbaden: Vieweg + Teubner.

Taleghani, Mahmoud. 2010. La maison Amini. Patrimoine de l'architecture rurale du Guilan plaine centrale. Tehran: Rozaneh.

Zargar, Akbar. 2007. An Introduction to the Iranian Rural Architecture. Tehran: Dānišgāh-i Šahìd Bihištī.

\section{Elektronické zdroje}

IICAR - multidisciplninární výzkumné a vzdělávací středisko Institut aplikovaného výzkumu íránské kultury. [2020-06-26] Dostupné z: http://iicar.ut.ac.ir/ShowContent.aspx?PageID=450.

University of Yazd - Architecture. [2020-06-26] Dostupné z: https:// yazd.ac.ir/en/schools/art/dept/architecture.

Esfahak Historic Village. [2020-06-26] Dostupné z: http://www.caoi.ir/ en/projects/item/1038-esfahak-historic-village.html. 


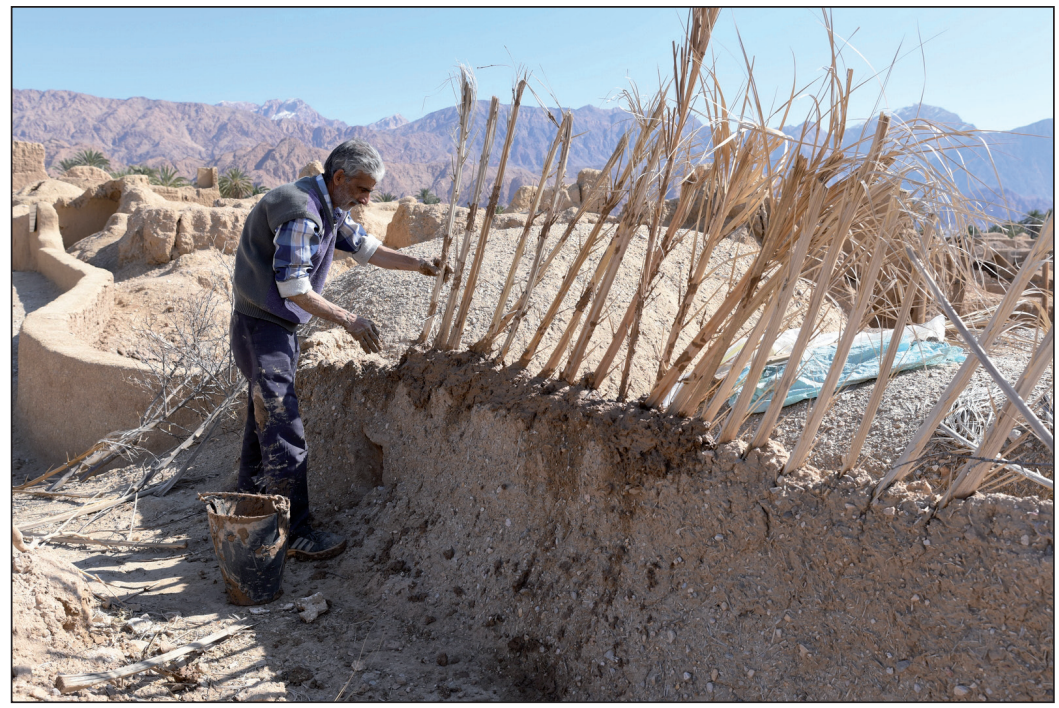

Obr. 1 Esfahak - oprava hliněného zdiva vyztuženého palmovými listy. Foto M. Novotný, 2019.

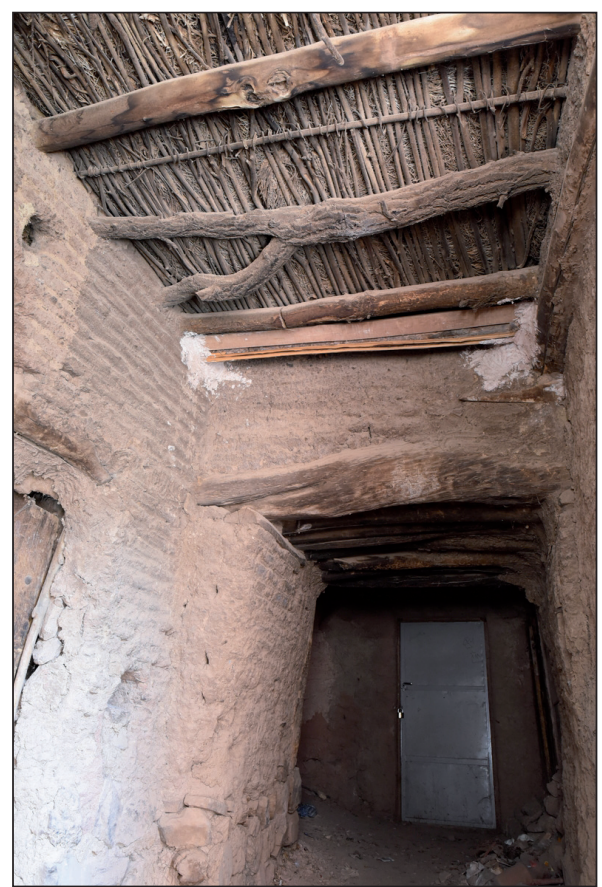

Obr. 2 Abyaneh - subtilní konstrukce stropu. Foto M. Novotný, 2019. 


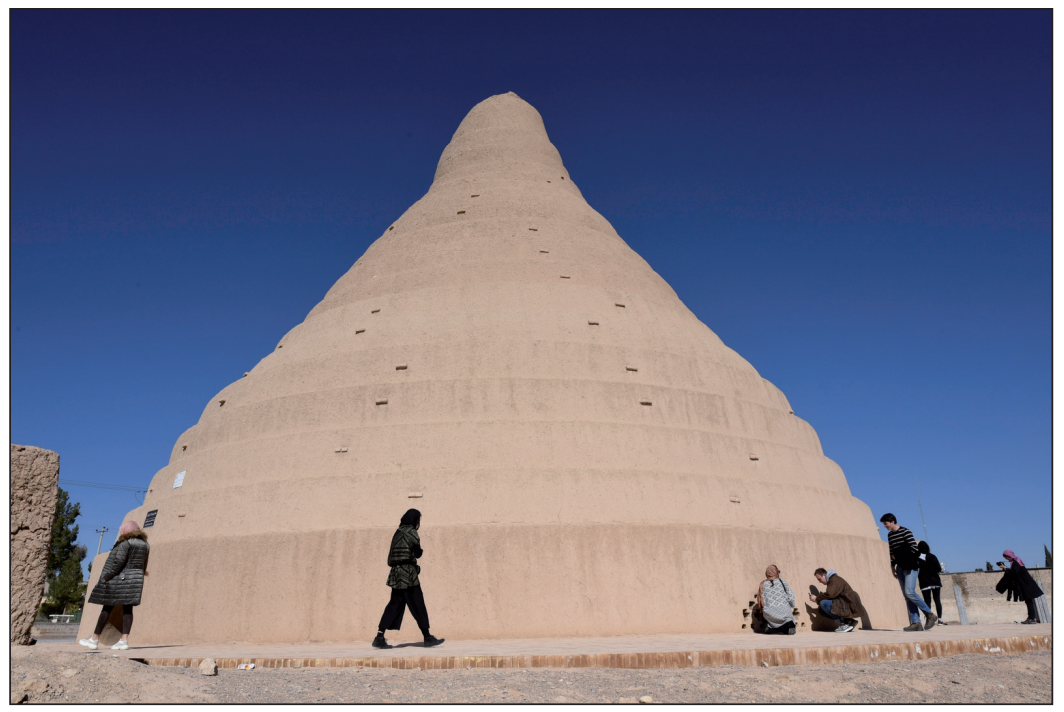

Obr. 3 Abarkuh - zásobník ledu (Yakhal) zbudovaný z nepálených cihel. Foto M. Novotný, 2019.

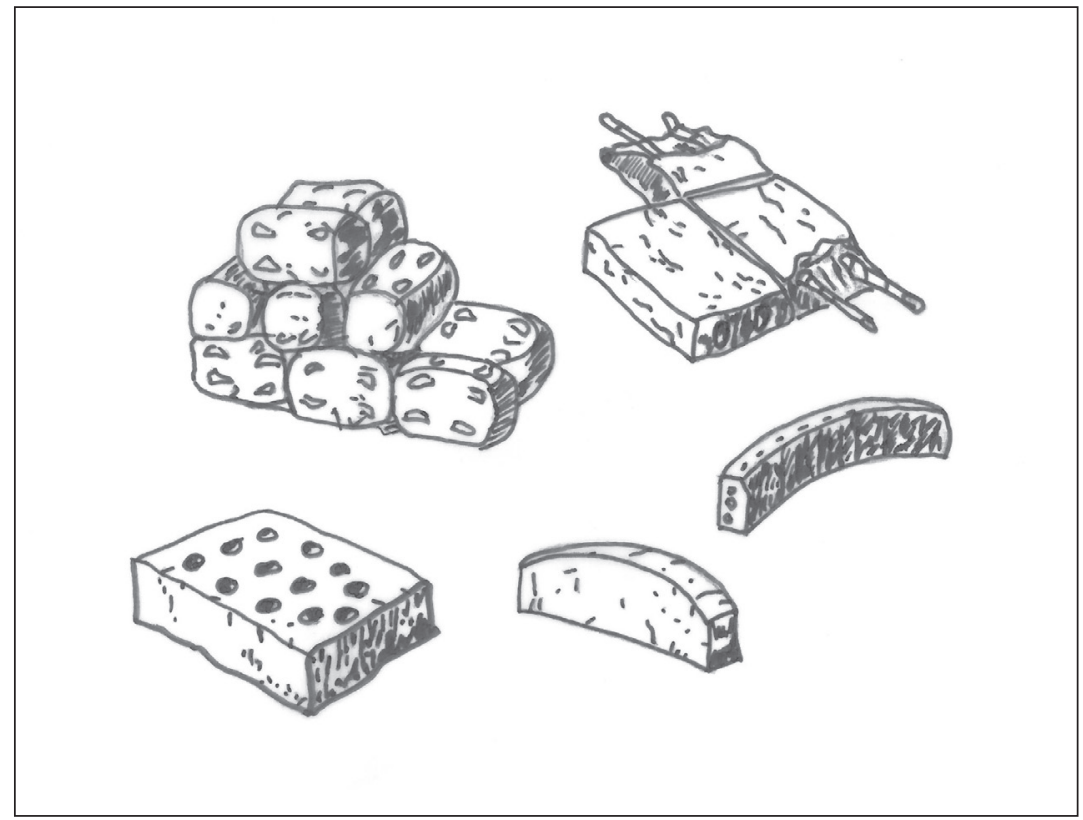

Obr. 4 Historické hliněné konstrukční prvky z Íránu a Afghánistánu (4. tisíciletí př. n. l. - 6. století n. 1.). Dle Schröder 2010. 


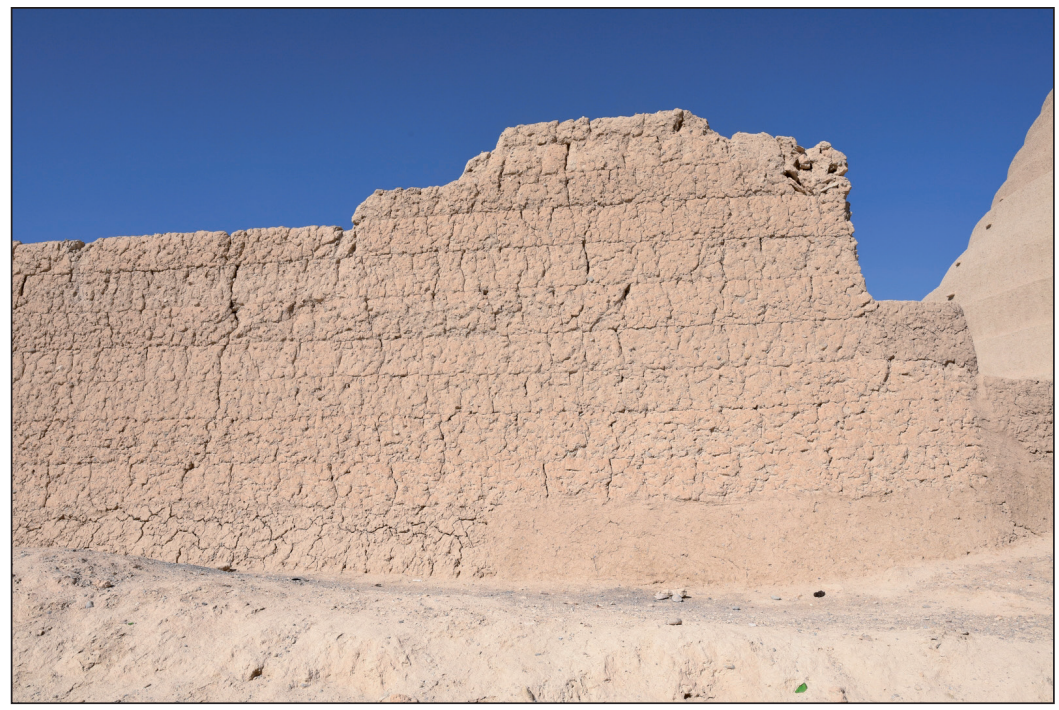

Obr. 5 Abarkuh - struktura vrstveného hliněného zdiva (čine). Foto M. Novotný, 2019.

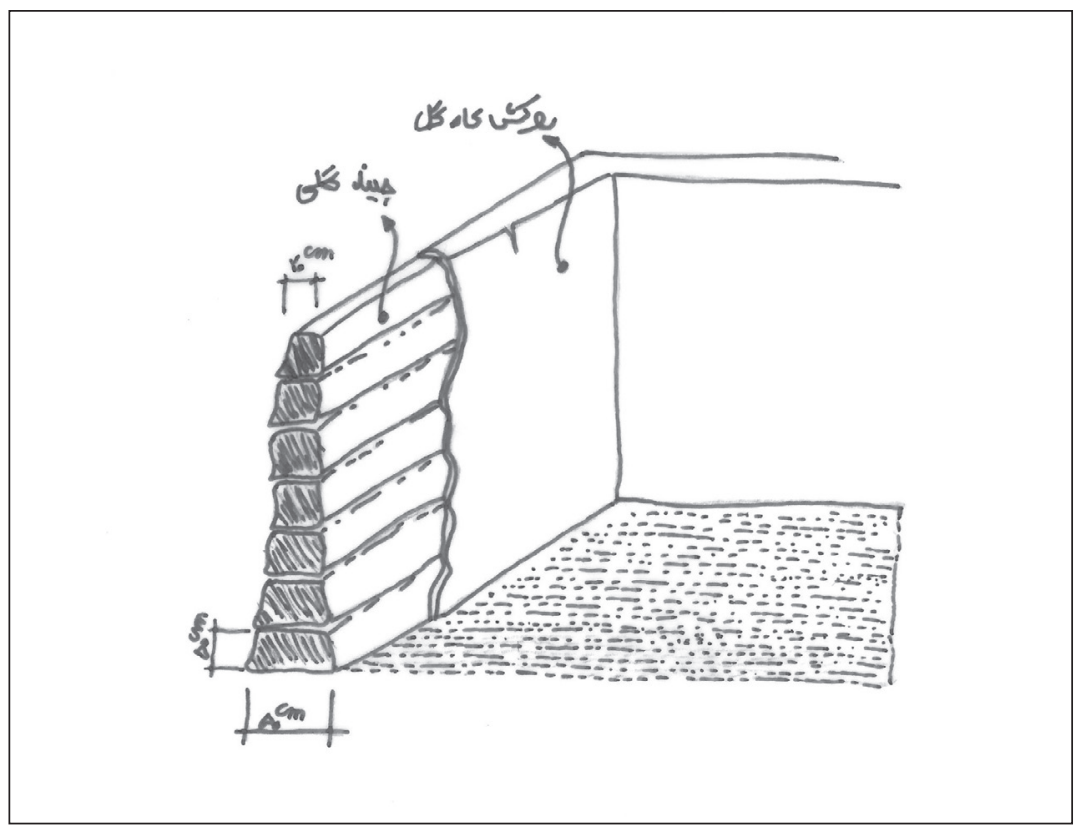

Obr. 6 Struktura kónicky se sbíhajícího vrstveného zdiva (čine). Dle Zargar 2007. 


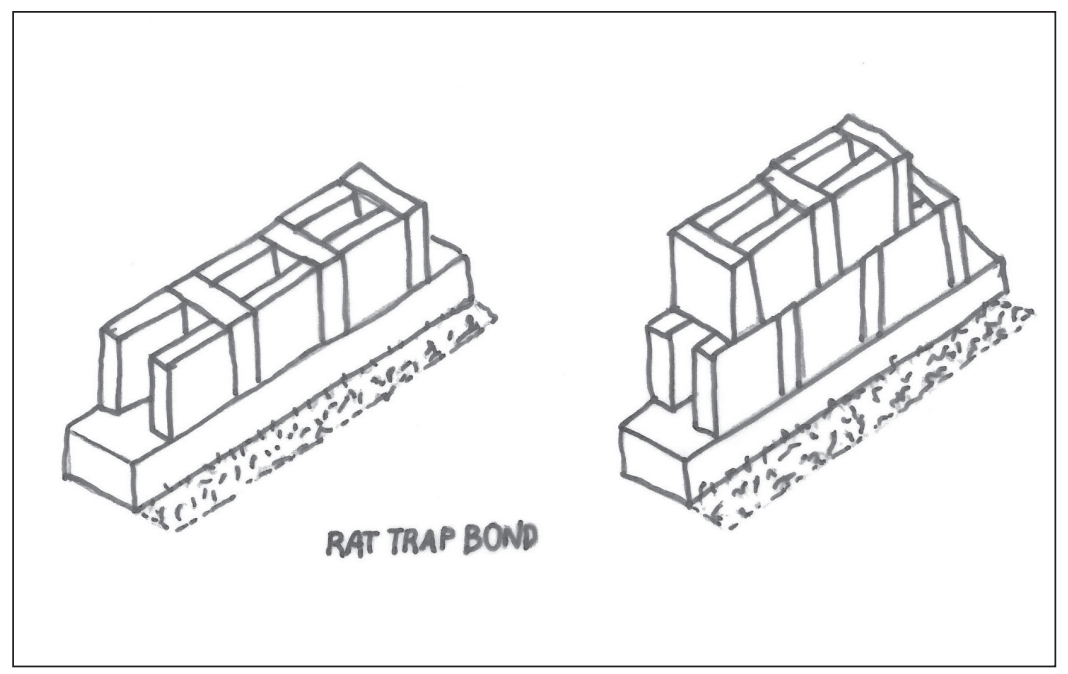

Obr. 7 Struktura „komůrkového zdiva“. Dle Ghobadian 2009.

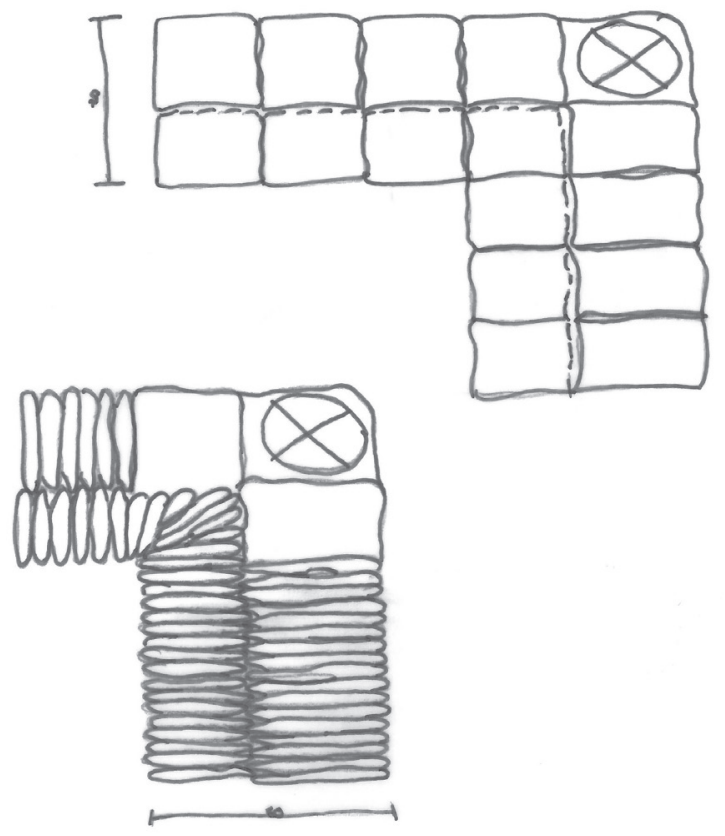

Obr. 8 Půdorysný pohled na strukturu klasovitě kladeného zdiva z nepálených cihel. Dle Taleghani 2010. 


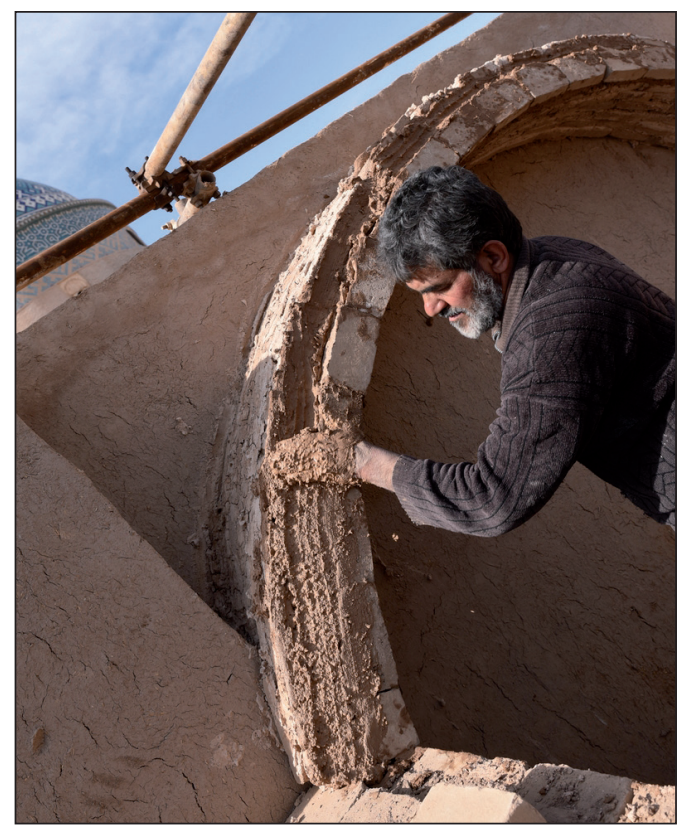

Obr. 9 Jazd - workshop zaměřený na revitalizaci tradiční hliněné architektury, pořádaný Fakultou architektury tamní univerzity. Foto M. Novotný, 2019.

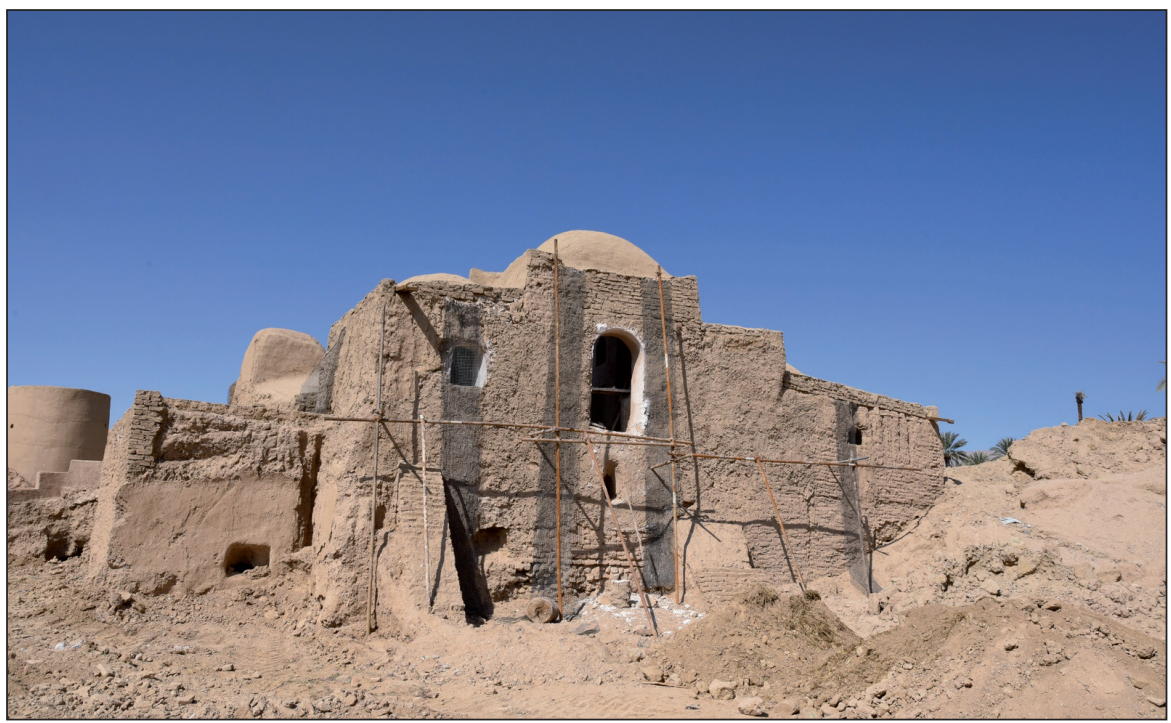

Obr. 10 Esfahak - oprava vesnice opuštěné po zemětřesení v roce 1978. Foto M. Novotný, 2019. 


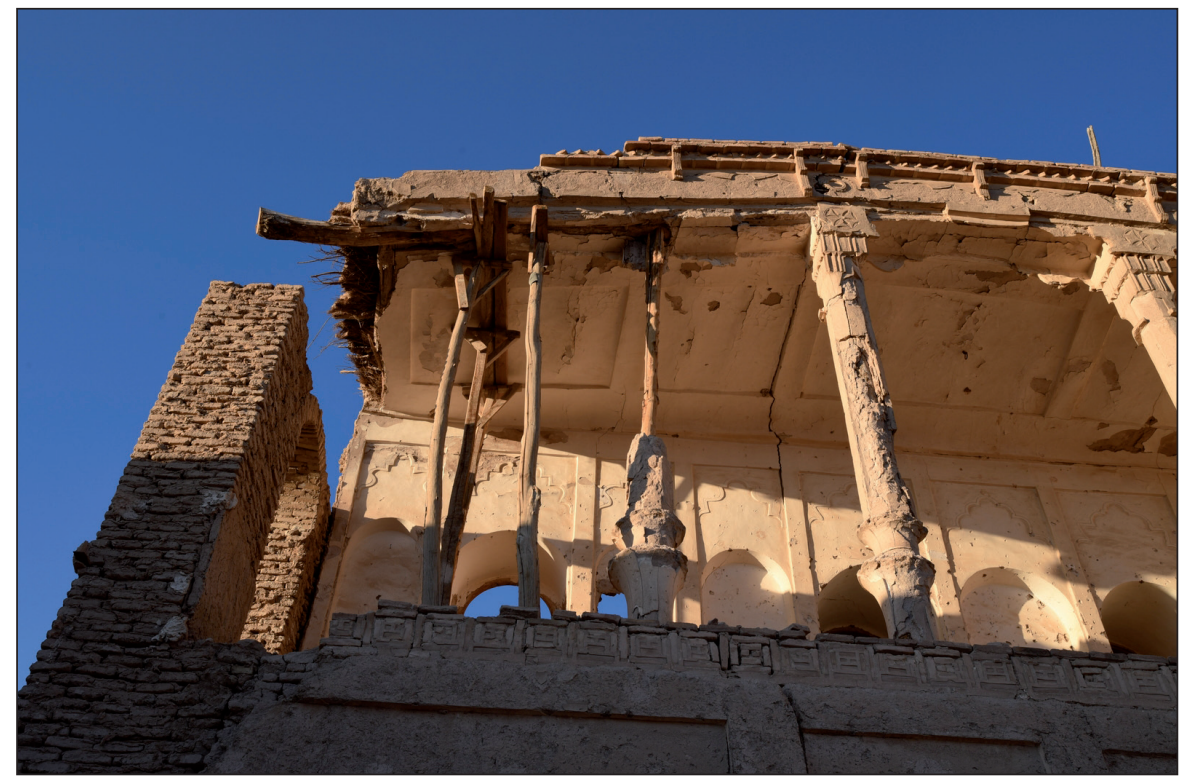

Obr. 11 Abarkuh - ruiny objektů jako klíč k pochopení místní architektury. Foto M. Novotný, 2019.

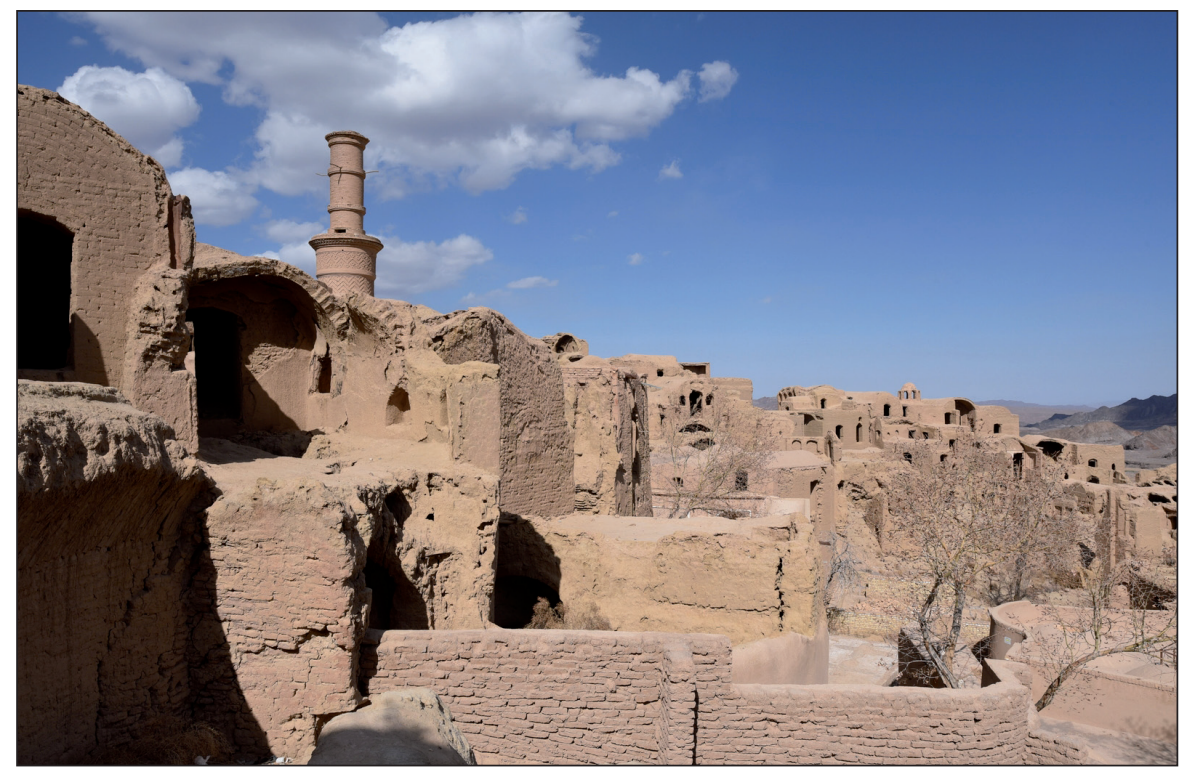

Obr. 12 Khanaraq - opuštěné hliněné jádro obce, které je dnes př́stupné turistům. Foto M. Novotný, 2019. 